\title{
Melanosis of The Appendix Presenting with the Clinic of Acute Appendicitis
}

\section{Akut Apandisit ile Bulgu Veren Appendiks Melanozisi}

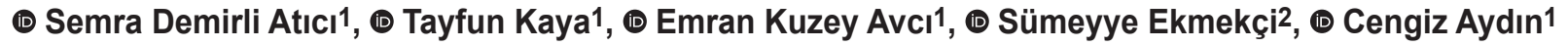 \\ 1 University of Health Sciences Tepecik Training and Research Hospital, Clinic of General Surgery, Izmir, Turkey \\ 2University of Health Sciences Tepecik Training and Research Hospital, Clinic of Pathology, İzmir, Turkey
}

\section{|IIIIIIII| ABSTRACT}

Laxative drugs are frequently used for chronic constipation. The chronic use of laxatives, which contain anthraquinone, mostly causes melanosis coli. A 57-year-old male patient with a history of diabetes mellitus and coronary artery disease, had long-term laxative use due to chronic constipation. The patient was admitted to the emergency service with the complaint of inflammatory abdominal pain that started in the epigastric region one day ago and migrated to the right lower quadrant. During the physical examination, right lower quadrant tenderness and rebound were positive. Imaging examinations and physical examination were consistent with acute appendicitis. The patient underwent an appendectomy via Mc Burney incision under general anesthesia. The postoperative follow-up period was complication-free and the patient was discharged on the second postoperative day. Postoperative specimen pathology was reported as an appendix with melanosis coli findings.

The incidence of melanosis coli increases with the chronic use of laxative drugs. Although melanosis coli is seen as a benign disease, there are no accurate data about whether it increases the risk of colon cancer and the incidence of acute appendicitis.

Keywords: Melanosis coli, laxative, colon cancer, appendix

\section{|IIIIIII| ÖZ}

Laksatif ilaçlar genellikle kronik konstipasyon şikayeti nedeniyle kullanılmaktadır. Antrakinon içerek laksatif ilaçların uzun süre kullanımı sıklıkla melanozis koliye sebep olmaktadır. Fifty-seven yaşında bilinen diyabet, koroner arter hastalığı, kronik konstipasyon nedeniyle uzun sureli laksatif kullanımı olan erkek hasta, bir gündür olan epigastrik bölgeden başlayan ve sağ alt kadrana migrasyon gösteren enflamatuvar tarzda karın ağrısı yakınması, iştahsızlık, bulantı ve kusma şikayeti ile acil servise başvurdu. Yapılan fizik muayenesinde sağ alt kadranda hassasiyet ve rebound pozitifti. Yapılan laboratuvar tetkiklerinde lökositozu olan, abdomen ultrasonografi ve fizik muayenesi akut apandisiti destekleyen hasta acil operasyona alındı. Hastaya genel anestezi altında Mc Burney insizyonla apendektomi uygulandı. Servis izleminde ek bir komplikasyon gözlenmeyen hasta, postoperatif ikinci gün taburcu edildi. Hastanın postoperatif spesimen patolojisi melanozis koli bulguları gösteren apendiks şeklinde raporlandı. Melanozis koli görülme insidansı kronik laksatif kullanımı ile birlikte artmaktadır. Melanozis koli benign bir hastalık olarak görülmekle birlikte, kolon kanser riskini ve akut apandisit insidansını arttırıp arttırmadığına yönelik kesin veriler bulunmamaktadır.

Anahtar Kelimeler: Melanozis koli, laksatif, kolon kanseri, apendiks

\section{Introduction}

Melanosis coli (MC) is a dark brown pigmentation of the colonic mucosa and also named as psodomelanosis coli. ${ }^{1,2}$ MC often affects the cecum; the rectum is mostly affected secondary to the chronic use of anthraquinone-containing laxatives. ${ }^{2,3}$ MC was first described by Cruveilhier in 1829, and named MC by Virchow in 1857.,2

\section{Case Report}

A 57-year-old male patient with a history of diabetes mellitus and coronary artery disease was admitted to the emergency department with the complaints of abdominal pain, appetite loss, nausea, and vomiting. The abdominal pain started in the epigastric region one day ago and migrated to the right lower quadrant. In the physical examination, right lower quadrant

Address for Correspondence/Yazışma Adresi: Semra Demirli Atıcı MD,

University of Health Sciences Tepecik Training and Research Hospital, Clinic of General Surgery, İzmir, Turkey

Phone: +90 5363624585 E-mail: smrdemirli@hotmail.com ORCID ID: orcid.org/0000-0002-8287-067X

Received/Geliş Tarihi: 22.10.2019 Accepted/Kabul Tarihi: 25.11.2019

${ }^{\circ}$ Copyright 2020 by Turkish Society of Colon and Rectal Surgery

Turkish Journal of Colorectal Disease published by Galenos Publishing House. 
tenderness and rebound were positive. The patient had chronic constipation and had a history of long term anthraquinone-containing laxative use. The laboratory tests showed leukocytosis. Abdominal ultrasonography and physical examination supported the diagnosis of acute appendicitis. The patient underwent an emergency operation. Appendectomy was performed via Mc Burney incision under general anesthesia. Postoperative follow-up was uneventful, and the patient was discharged on the second postoperative day without any complication. Postoperative histopathological examination of the specimen was reported as appendix tissue with the findings of MC (Figure 1, 2). In the appendix tissue, histiocytes and some pigmented deposition of histiocytes and histiocytes in the lamina propria were scattered in small groups. Histochemical staining showed no intracytoplasmic pigment staining with iron. The patient was advised to stop taking the laxative, and dietary modifications were adjusted for constipation. Total colonoscopy was performed two months after the surgery, and no additional pathology was observed.

\section{Discussion}

The rate of laxative use due to chronic constipation has increased with a sedentary lifestyle. Constipation is a frequently seen gastrointestinal problem, and anthraquinone containing laxatives are frequently used for chronic constipation. ${ }^{1,2}$

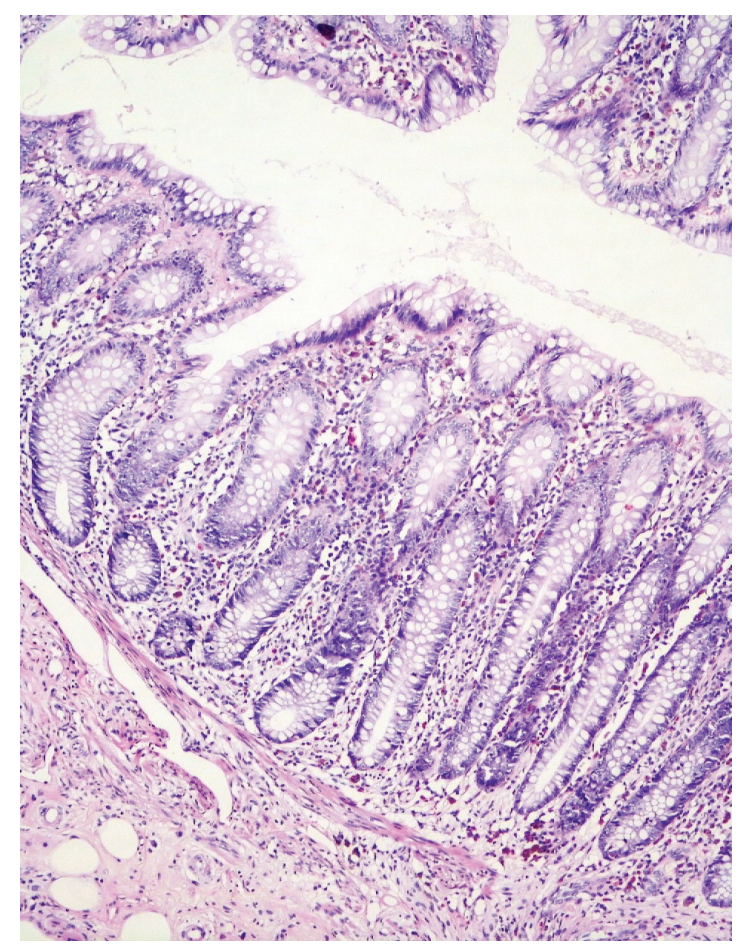

Figure 1. Histiocytes containing brown pigment deposits in the lamina propria of appendiceal mucosa (Hematoxylin and eosin, original magnification $\mathrm{x}$ 100)
MC is mostly seen as a brownish discoloration of the colonic mucosa during a colonoscopy and occurs due to the chronic use of laxatives drugs, especially anthraquinone-containing laxatives. ${ }^{1} \mathrm{MC}$ is reported to be seen more commonly in the female population. The female-male ratio is two., ${ }^{1,2}$ Although it is frequently located in the colonic mucosa, especially in the the cecum part, MC can be seen in the small intestine as well. ${ }^{3}$ However, it may be seen in patients with chronic diarrhea, inflammatory bowel disease, and chronic use of non-steroidal anti-inflammatory drugs., ${ }^{3,45}$ Improper laxative use due to chronic constipation may cause MC, which is more common in elder patients., ${ }^{1,2}$ Acute appendicitis is one of the most common causes of abdominal pain in patients admitted to the emergency department. The most common etiology is lymphoid hyperplasia and obstruction. In the literature, there are many cases and case series operated for acute appendicitis, and histopathologic examination revealed appendix melanosis. Histological examinations of postoperative appendectomy specimens and MC have been extensively studied, but no specific studies have been conducted to determine whether MC is involved in the etiology of acute appendicitis or not. In a study by Rutty et al. ${ }^{1}, 7.4 \%$ of appendix melanosis was reported in adult patients operated for acute appendicitis. Graf et al. ${ }^{6}$ reported $46 \%$ melanosis in 300 appendectomy specimens in the pediatric age group, most of whom were operated for acute appendicitis and abdominal pain. In addition, in this study, the incidence of melanosis was reported to increase with increasing age. Walker et al. ${ }^{7}$ reported that hyperpigmented macrophages due to melanosis migrated to the regional lymph nodes that persisted even after the elimination of the stimulus for submucosa and epithelial apoptosis, and Graf et al. ${ }^{6}$

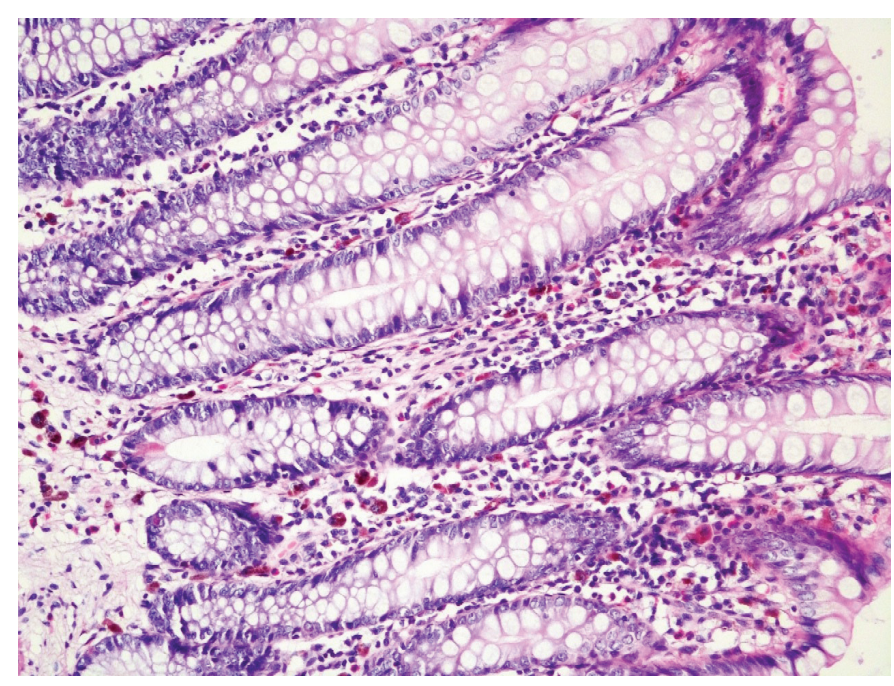

Figure 2. Histiocytes containing brown pigment deposits in the lamina propria of appendiceal mucosa (Hematoxylin and eosin, original magnification x 200) 
reported that pigmented macrophages reduced lymphatic clearance. In the literature, Malik et al. ${ }^{8}$ reported a patient operated for colonic pseudoobstruction secondary to melanosis coli. Although there are no studies on this subject, it is known that the etiology of appendicitis is lymphoid hyperplasia and often secondary to fecaloid obstruction. We think that increased epithelial apoptosis and obstruction secondary to decreased lymphoid clearance may play a role in the presentation of patients with appendix melanosis with an acute appendicitis clinic. $\mathrm{MC}$ is the dark brown pigmentation of the colonic mucosa caused by the accumulation of pigments in the macrophages of lamina propria. ${ }^{1}$ Although the tissue does not contain melanin pigments, the dark pigmentation which has an appearance like melanosis occur due to the increased apoptosis of epithelial cells and lipofuscin. This appearance has consisted of the lipofuscin granules, which occur secondary to the obliteration of apoptotic epithelial cells. ${ }^{9}$ The relationship of MC and neoplasia of the colonic epithelium has long been a subject of interest, but it remains unclarified. ${ }^{1,3}$ Studies have shown that there was an association between $\mathrm{MC}$ and the increase in colonic epithelial cell apoptosis. ${ }^{2,3}$ Although MC is usually benign and reversible and resolves within one year after the discontinuation of anthraquinone containing laxatives, there is an increased risk of colorectal carcinoma, which has also been discussed. ${ }^{2,3}$ Lui et al. ${ }^{3}$ reported that MC was associated with a higher number of colorectal polyps significantly. Moreover, they reported that MC was associated with a higher incidence and number of colonic non-adenoma polyps and low-grade adenomas and higher incidence of distal ileal ulcers due to the chronic injury of colonic and intestinal mucosa. ${ }^{3}$ In conclusion, although MC is seen as a benign disease, it may be related to an increased risk of acute appendicitis and colorectal carcinoma, which should always be kept in mind, and total colonoscopy is recommended. There are no accurate data as to whether it increases the risk of acute appendicitis and colon cancer. Larger case series are needed to make this relationship clear.

\section{Ethics}

Informed Consent: Written informed consent was obtained from the patient for publication and any accompanying images.

Peer-review: Internally peer reviewed.

\section{Authorship Contributions}

Surgical and Medical Practices: E.K.A., T.K., Concept: E.K.A., S.E., Design: S.D.A., C.A., Data Collection or Processing: E.K.A, S.E., Analysis or Interpretation: T.K., C.A., Literature Search: S.D.A., T.K., C.A., Writing: S.D.A. Conflict of Interest: No conflict of interest was declared by the authors.

Financial Disclosure: The authors declared that this study received no financial support.

\section{References}

1. Rutty GN, Shaw PA. Melanosis of the appendix: prevalence, distribution and review of the pathogenesis of 47 cases. Histopathology 1997;30:319323.

2. Akbayir N, Yildirim S, Sökmen HM, Kiliç G, Erdem L, Alkim C. Intussusception of vermiform appendix with microscopic melanosis coli: a case report. Turk J Gastroenterol 2006;17:233-235.

3. Liu ZH, Foo DCC, Law WL, Chan FSY, FanJKM, Peng JS. Melanosis coli: Harmlesspigmentation? A case-control retrospective study of 657 cases. PLoS One 2017;12:e0186668.

4. Byers RJ, Marsh P, Parkinson D, Haboubi NY. Melanosis coli is associated with an increase in colonic epithelial apoptosis and not with laxative use. Histopathology 1997;30:160-164.

5. Marshall JB, Singh R, Diaz-Arias AA. Chronic, unexplained diarrhea: are biopsies necessary if colonoscopy is normal? Am J Gastroenterol 1995;90:372-376.

6. Graf NS, Arbuckle S, Melanosis of the appendix: common in the paediatric age group. Histopathology 2001;39:243-249

7. Walker NI, Bennett RE, Axelsen RA. Melanosis coli. A consequence of anthraquinone-induced apoptosis of colonic epithelial cells. Am J Pathol 1988;131:465-476.

8. Malik AH, Andrabi SI, Niayesh M. Pseudo-obstruction with pitch black colon - A very rare Presentation of Melanosis Coli. Ulster Med J 2008;77:5455 .

9. Freeman HJ. "Melanosis" in the small and large intestine. World J Gastroenterol 2008;14:4296-4299. 